\title{
Efektivitas LKS IPA Terpadu Berorientasi Model Pembelajaran Berbasis Masalah terhadap Kognitif Siswa SMP Kelas VII
}

\author{
Elfa Oprasmani \\ Program Studi Pendidikan Biologi, Fakultas Keguruan dan Ilmu Pendidikan, Universitas Maritim Raja Ali Haji, \\ Tanjungpinang, Indonesia
}

Pengiriman: 13 Juli 2018; Diterima: 2 Oktober 2018; Publikasi: Nopember 2018

\begin{abstract}
One of the goals Curriculum 2013 is to form students are able to perform troubleshooting. In fact the problems found in the junior high school in Pekanbaru the problem solving and critical thinking of students have not been able to be trained optimally. Based on these problems need to be developed worksheets that trains student's problem-solving ability. This research aims to know effectivity of Integrated Science student worksheet oriented Problem Based Learning model to cognitive of junior high school Class VII. This research was a quasi experimental research. The trial subject of the research were grade VII studens of SMP Negeri 23 Pekanbaru. The class used in the worksheet trial was chosen by looking at the normality dan homogenity of student test result. Hypothesis test was done using SPSS 16 . The results of this research indicated that student's cognitive learning outcome have value Sig 0,018. The conclusion of this research was Integrated Science student worksheet oriented Problem Based Learning model effective on student's cognitive learning outcome.
\end{abstract}

Keywords: Effectivity, Worksheet, Problem Based Learning model

\begin{abstract}
ABSTRAK: Salah satu tujuan Kurikulum 2013 yaitu untuk membentuk siswa yang mampu melakukan pemecahan masalah. Kenyataannya, permasalahan yang ditemukan pada SMP di Pekanbaru kemampuan pemecahan masalah dan berfikir kritis siswa belum mampu dilatih secara maksimal. Berdasarkan permasalahan tersebut perlu dikembangkan LKS yang melatih kemampuan pemecahan masalah siswa. Penelitian ini bertujuan untuk mengetahui efektivitas LKS IPA Terpadu Berorientasi model Pembelajaran Berbasis Masalah terhadap konitif siswa SMP kelas VII. Penelitian ini merupakan penelitian kuasi eksperimen. Subjek uji coba pada penelitian ini adalah siswa kelas VII SMP Negeri 23 Pekanbaru. Kelas yang digunakan dalam uji coba LKS dipilih dengan melihat normalitas dan homogenitas hasil ulangan siswa. Uji hipotesis dilakukan dengan menggunakan bantuan SPSS 16. Hasil penelitian menunjukkan bahwa hasil belajar kognitif siswa memiliki nilai Sig 0,018. Kesimpulan dalam penelitian ini LKS IPA Terpadu Berorientasi model Pembelajaran Berbasis Masalah berpengaruh terhadap hasil belajar kognitif siswa.
\end{abstract}

Kata Kunci: Efektivitas, LKS, Model Pembelajaran Berbasis Masalah

*Penulis Korespondensi:

Alamat surel: elfaoprasmani@gmail.com 


\section{PENDAHULUAN}

Kurikulum 2013 bertujuan menciptakan manusia yang mandiri, mampu memecahkan masalah, mempunyai kepribadian yang kuat, inovatif dan kreatif serta menguasai teknologi. Berdasarkan Permendikbud No 65 Tahun 2013 tentang Standar Proses Pendidikan Dasar dan Menengah menyebutkan bahwa, "Sesuai dengan Standar Kompetensi Lulusan dan Standar Isi, maka prinsip pembelajaran yang digunakan dari pembelajaran parsial menuju pembelajaran terpadu.

Salah satu pembelajaran yang memakai prinsip keterpaduan di Sekolah Menengah Pertama yaitu IPA Terpadu yang mengintegrasikan pembelajaran Biologi, Fisika dan Kimia. Ahmadi dan Amri (2014: 84) menyatakan pembelajaran yang terpadu menuntut siswa untuk lebih mengembangkan keterampilan, memproses pemerolehan, mengamati/mengobservasi, membuat hipotesis, merencanakan penelitian, mengendalikan variabel, menafsirkan data, menyusun kesimpulan, membuat prediksi, menerapkan dan mengkomunikasikan /mempresentasikan.

Salah satu tujuan dari pembelajaran IPA Terpadu di SMP menurut Permendikbud 64 Tahun 2013 adalah untuk memahami konsep dan prinsip IPA serta saling keterkaitannya dalam menyelesaikan masalah.

Berdasarkan hasil wawancara dengan guru IPA diketahui bahwa siswa belum mampu memecahkan masalah serta mengkaitkan konsep IPA dalam kehidupan sehari-hari. Selain itu, masih banyak siswa yang memiliki hasil belajar di bawah KKM.
Salah satu usaha membiasakan siswa melakukan pemecahan masalah dalam pembelajaran dan meningkatkan kemampuan kognitif siswa yaitu dengan menggunakan LKS.yang diorientasi dengan model Pembelajaran Berbasis Masalah. Berdasarkan hasil penelitian Bariroh, dkk (2014: 127) LKS IPA Terpadu berbasis pembelajaran berdasarkan masalah tema polusi cahaya kelas VIII, LKS yang dikembangkan dapat meningkat hasil belajar siswa dan kinerja siswa, serta memancing kemampuan berfikir kritis siswa serta bersikap mandiri.

Model Pembelajaran Berbasis Masalah penting digunakan dalam pembelajaran karena dapat menumbuhkan inisiatif siswa dalam bekerja, motivasi internal untuk belajar, dan dapat mengembangkan hubungan interpersonal dalam bekerja kelompok. Menurut penelitian yang dilakukan Af'idah dkk (2013: 67) pembelajaran berdasarkan masalah menuntut siswa menyelami penyelidikan secara autentik dan berusaha memperoleh pemecahan-pemecahan terhadap masalah-masalah nyata serta mengembangkan keterampilan sosial siswa.

Berdasarkan latar belakang yang dikemukakan maka rumusan masalah dalam penelitian ini adalah Bagaimanakah efektivitas LKS IPA Terpadu berorientasi model Pembelajaran Berbasis Masalah kelas VII terhadap hasil belajar kognitif siswa?

Penelitian ini bertujuan untuk mengetahui efektivitas LKS IPA Terpadu berorientasi model Pembelajaran Berbasis Masalah kelas VII terhadap hasil belajar kognitif siswa.

Penelitian ini bermanfaat bagi guru dan siswa sebagai alternatif bahan ajar untuk 
mengembangkan pengetahuan, sikap dan keterampilan siswa, serta meningkatkan kemampuan pemecahan masalah siswa sesuai dengan tujuan kurikulum 2013.

\section{METODE PENELITIAN}

Subjek uji coba pada penelitian ini adalah siswa kelas VII SMP Negeri 23 Pekanbaru. Kelas yang digunakan dalam uji coba LKS dipilih dengan melihat normalitas dan homogenitas hasil ulangan siswa, selanjutnya ditentukan kelas eksperimen dan kelas kontrol secara acak. Kelas eksperimen yaitu kelas VII D dan Kelas Kontrol kelas VII A.

Penilaian ranah kognitif dilakukan dengan mengadakan tes tertulis untuk mengetahui hasil belajar siswa dengan menggunakan bentuk tes pilihan ganda. Tes pilihan ganda yang diberikan terlebih dahulu harus dilakukan uji reabilitas, daya beda dan tingkat kesukaran soal tes yang akan digunakan. Hasil perhitungan tingkat kesukaran soal tes dalam penelitian ini pada materi pemisahan campuran yang memiliki kriteria mudah 2 soal, sedang 16 soal dan sukar 2 soal. Hasil perhitungan daya beda soal tes dalam penelitian ini pada materi pemisahan campuran yang memiliki kriteria baik 8 soal, cukup 5 soal dan jelek 7 soal. Hasil perhitungan koefisien reliabilitas untuk 15 soal tes dalam penelitian ini adalah 0,71 .

Nilai dari tes objektif dihitung menggunakan rumus sebagai berikut (Sudijono, 2011: 308).

$$
\text { Nilai }=\frac{\text { Skor mentah }}{\text { Skor maksimum ideal }} \times 100 \%
$$

Bila ketuntasan individual lebih besar atau sama dengan Kriteria Ketuntasan Minimal (KKM) maka siswa dinyatakan tuntas, dasar kriteria KKM digunakan adalah kriteria yang dipakai di SMP Negeri 23 Pekanbaru yaitu 2,67 (B). Dari persentase yang diperoleh dilakukan pengelompokan sesuai dengan kriteria seperti Tabel 1.

Tabel 1. Kriteria Ketuntasan Belajar

\begin{tabular}{ll}
\hline Kisaran Ketuntasan & Ketuntasan \\
\hline$\geq$ KKM & Tuntas \\
$\leq$ KKM & Tidak tuntas \\
\hline
\end{tabular}

Tahap analisis data meliputi, uji normalitas, uji homogenitas dan uji hipotesis dilakukan dengan menggunakan SPSS 16.

1. Uji Normalitas

Uji normalitas dilakukan dengan menggunakan uji Kolomogorov-Smirnov dengan menggunakan SPSS 16. Data berdistribusi normal apabila PValue/Sig yang diperoleh lebih besar dari taraf nyata $(\alpha)=0,05$. Hipotesis sebagai berikut.

$\mathrm{H}_{0}$ : data mengikuti suatu distribusi normal.

$\mathrm{H}_{1}$ : data tidak mengikuti suatu distribusi normal.

2. Uji Homogenitas

Uji homogenitas dilakukan dengan menggunakan uji Levene dengan bantuan SPSS 16. Data homogen apabila nilai sig $>$ taraf nyata $(\alpha=$ $0,05)$.

\section{Uji Hipotesis}

Pengujian hipotesis pada penelitian dilakukan pada taraf nyata $\frac{1}{2} \alpha(\alpha=0,05)$. Uji hipotesis dilakukan dengan menggunakan bantuan SPSS 16. Uji statistik apabila data berdistribusi normal dan homogen yaitu dengan menggunakan uji t. Kriteria 
pengujiannya adalah bila harga sig. $<\frac{1}{2} \alpha$ maka $\mathrm{H}_{1}$ diterima, sebaliknya sig. $>\frac{1}{2} \alpha$ maka $\mathrm{H}_{0}$. Dengan $\mathrm{dk}=\mathrm{n}_{1}+\mathrm{n}_{2}-2$. Sementara apabila data tidak berdistribusi normal maka dilakukan uji Mann Whitney $U$. Hipotesis dalam penelitian ini adalah sebagai berikut.

$\mathrm{H}_{0}: \mu_{1} \leq \mu_{2}$

$\mathrm{H}_{1}: \mu_{1}>\mu_{2}$

Keterangan:

$\mu_{1}$ : hasil belajar siswa yang menggunakan LKS

IPA Terpadu berorientasi model Pembelajaran Berbasis Masalah.

$\mu_{2}$ : hasil belajar siswa yang tidak menggunakan LKS IPA Terpadu berorientasi model Pembelajaran Berbasis Masalah.

\section{HASIL DAN PEMBAHASAN}

a. Karakteristik LKS IPA Terpadu Berorientasi model Pembelajaran Berbasis Masalah

\section{1) Aspek Kontruksi}

LKS yang digunakan dalam perlakuan memuat langkah-langkah model Pembelajaran Berbasis Masalah yang diterapkan Jordan dkk dalam Tan ((2009: 58-59) yakni.

\section{a) Menyajikan permasalahan.}

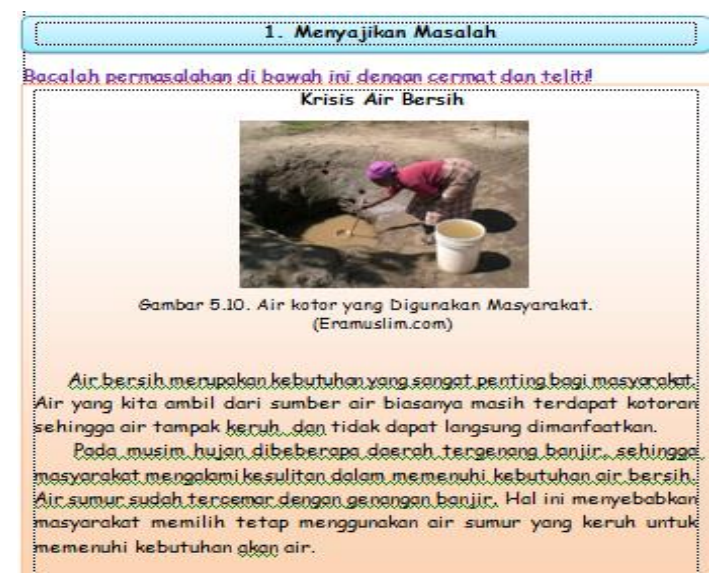

Gambar 1. Menyajikan permasalahan

Permasalahan yang digunakan permasalahan kehidupan nyata yang telah diseleksi dan diedit untuk menemukan objek dan kriteria yang sesuai dengan pembelajaran.

b) Melibatkan siswa dalam permasalahan dan mendefinisikan hal yang harus dipelajari.

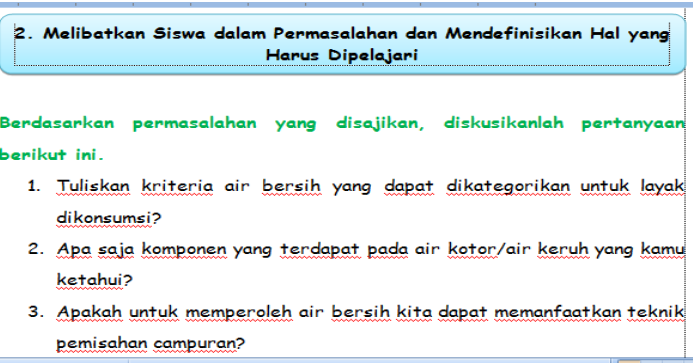

Gambar 2. Tahap melibatkan siswa dalam permasalahan dan mendefinisikan hal yang harus dipelajari

Pada tahap ini siswa diorganisasikan dalam kelompok dalam memaknai permasalahan dan mendefinisikan hal yang harus dipelajari. Pertanyaan-pertanyaan disajikan untuk mengetahui pengetahuan siswa berkaitan dengan permasalahan yang disajikan.

c) Siswa mencari informasi/melakukan penyelidikan untuk memperoleh fakta yang relevan.

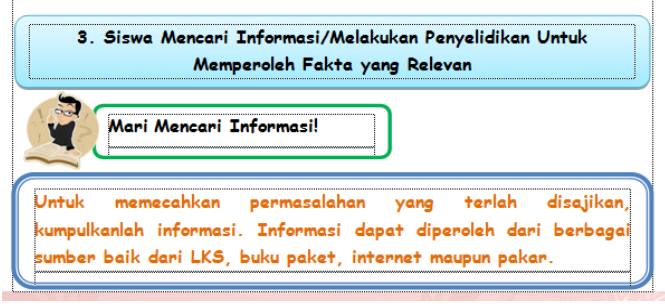

Gambar 3. Tahap siswa mencari informasi/melakukan penyelidikan untuk memperoleh fakta yang relevan 
Kegiatan ini dapat dilihat dengan siswa mengumpulkan data dari berbagai sumber sehingga siswa benar-benar memahami permasalahan.

\section{d) Siswa mengajukan solusi dan hasil diskusi.}

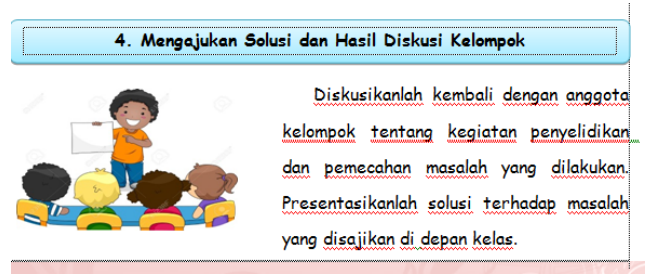

Gambar 4. Tahap siswa mengajukan solusi dan hasil diskusi

Setelah melakukan penyelidikan siswa mencari solusi yang tepat terhadap permasalahan yang disajikan. Selanjutnya solusi yang ditemukan disajikan di depan kelas.

\section{2) Aspek Isi}

Aspek Isi LKS berorientasi pembelajaran berbasis masalah ini memiliki spesifikasi sebagai berikut.

a) Materi disajikan dengan lengkap yang berkaitan dengan kegiatan pembelajaran yang akan dilaksanakan dan diberikan beberapa gambar yang berkaitan dengan materi, sebagai modal dasar bagi anak untuk menyelesaikan masalah.

b) Gambar yang disajikan jelas dan menarik untuk menjelaskan materi yang disajikan. Siswa lebih dapat mengingat teks bila dilengkapi dengan gambar (Jalilehvand, 2012: 331). c) Pertanyaan yang ada di dalam LKS memuat pertanyaan yang tidak terstruktur yang berdasarkan permasalahan sehari-hari.

\section{b. Hasil Analisis Deskriptif}

Hasil belajar kognitif siswa yang menggunakan LKS IPA terpadu berorientasi model Pembelajaran Berbasis Masalah lebih tinggi dibandingkan kelas kontrol. Nilai maksimun yang diperoleh kelas eksperimen juga lebih tinggi dibandingkan kelas kontrol. Ketuntasan klasikal kelas ekperimen mencapai $75 \%$ (Tabel 2).

Tabel 2. Hasil Tes Belajar Kognitif Siswa

\begin{tabular}{|c|c|c|c|c|c|}
\hline Kelas & $\mathbf{N}$ & $\overline{\mathbf{x}}$ & $\mathbf{X}_{\min } \mathbf{X}_{\max }$ & $\mathbf{S}$ & $\begin{array}{c}\begin{array}{c}\text { Ketuntasan } \\
\text { Klasikal } \\
(\mathbf{K K M}=\mathbf{2 , 7 5})\end{array} \\
\mathrm{KKM} \geq \mathrm{KKM}\end{array}$ \\
\hline Eksperimen & 40 & 2,94 & $1,88 \quad 3,72$ & 0,50912 & $\begin{array}{cc}30 & 10 \\
(75 \%) & (25 \%)\end{array}$ \\
\hline Kontrol & 40 & 2,67 & $\begin{array}{lll}1,60 & 3,72\end{array}$ & 0,47501 & $\begin{array}{cc}24 & 16 \\
(60 \%) & (40 \%)\end{array}$ \\
\hline
\end{tabular}

Berdasarkan hasil analisis deskriptif hasil belajar kognitif pada kelas eksperimen dan kelas kontrol menujukkan bahwa rata-rata hasil belajar kognitif kelas eksperimen lebih tinggi dibandingkan kelas kontrol. Ketuntasan klasikal pada kelas eksperimen lebih tinggi dibandingkan kelas kontrol. Hal ini disebabkan dengan menggunakan LKS IPA terpadu berorientasi masalah siswa terbiasa menemukan konsep-konsep dengan kegiatan pemecahan masalah yang dilakukan. Setelah dilakukan analisis terhadap pengaruh LKS IPA terpadu berorientasi model Pembelajaran Berbasis Masalah terdapat perbedaan 
nyata antara kelas eksperimen dan kelas kontrol. Hal ini berarti penggunaan LKS yang dikembangkan berpengaruh terhadap hasil kognitif siswa.

\section{c. Pengujian Persyaratan Analisis}

a) Uji Normalitas

Hasil uji normalitas diperoleh data bahwa hasil belajar kognitif berdistribusi normal, sedangkan hasil belajar afektif dan psikomotor tidak berdistribusi normal (Tabel 3). Apabila data berdistribusi normal maka perlu dilihat homogenitas data dengan melakukan uji homogenitas. Uji homogenitas dilakukan dengan menggunakan uji Levene.

Tabel 3. Hasil Uji Normalitas Terhadap Nilai Kompetensi Belajar Siswa

\begin{tabular}{cccl}
\hline $\begin{array}{c}\text { Ranah } \\
\text { Kompetensi } \\
\text { Belajar }\end{array}$ & Kelas & Sig. & Keterangan \\
\hline Kognitif & Eksperimen & 0,064 & Berdistribusi \\
& Kontrol & 0,159 & $\begin{array}{l}\text { Berdistribusi } \\
\text { normal }\end{array}$ \\
\hline
\end{tabular}

b) Uji Homogenitas Variansi

Hasil uji homogenitas hasil belajar kognitif memiliki variansi yang homogen karena Sig. $(0,509)>\boldsymbol{\alpha}(0,05)$ (Tabel 4).

Tabel 4. Hasil Uji Homogenitas Variansi Terhadap Nilai Kompetensi Belajar Siswa

\begin{tabular}{cccc}
\hline $\begin{array}{c}\text { Ranah } \\
\text { Kompetensi } \\
\text { Belajar }\end{array}$ & $\alpha$ & Sig. & Keterangan \\
\hline Kognitif & 0,05 & 0,509 & Homogen \\
\hline
\end{tabular}

c) Uji Hipotesis Hasil Belajar Kognitif

Hasil belajar kognitif siswa memiliki nilai Sig 0,018 (Tabel 5). Hal ini berarti nilai Sig $<1 / 2$ 0,05 .

Tabel 5. Hasil Uji Hipotesis Hasil Belajar Kognitif

\begin{tabular}{cccc}
\hline Kelas & N & Rata-rata & Sig \\
\hline Eksperimen & 40 & 2,94 & 0,018 \\
Kontrol & 40 & 2,67 & \\
\hline
\end{tabular}

Dengan demikian dapat disimpulkan bahwa LKS yang dikembangkan berpengaruh terhadap hasil belajar kognitif siswa. Pengaruh penggunaan LKS dikarenakan dalam LKS memuat langkah-langkah Pembelajaran Berbasis Masalah yang meningkatkan kemampuan berfikir siswa dan motivasi siswa. Masalah yang disajikan pada LKS membuat siswa tertarik untuk belajar, sehingga siswa aktif dalam proses pemecahan masalah dalam kelompok. Menurut Minarti dkk (2012: 109) dalam penelitiannya semakin banyak pengalaman yang diperoleh siswa melalui aktivitas belajar, semakin meningkat pula pemahaman siswa terhadap materi.

\section{Permasalahan yang disajikan dalam LKS} melatih siswa dalam berfikir kritis dan melatih keterampilan pemecahan masalah siswa sehingga siswa memperoleh pengetahuan dan konsep yang utuh dari materi pembelajaran. Menurut Rusman (2010: 242) masalah yang disajikan dalam Pembelajaran Berbasis Masalah menjadi titik tolak dalam pembelajaran sehingga siswa memahami prinsip serta mengembangkan keterampilannya.

$$
\text { Pembelajaran Berbasis Masalah }
$$

melibatkan siswa dalam pengumpulan informasi 
dan penyelidikan. Hal ini memungkinkan pembelajaran yang bermakna karena siswa membangun dan mengembangkan pengetahuan serta pemahamannya sendiri dari pengalamannya sendiri. Pembelajaran yang bermakna menyebabkan pengetahuan yang diperoleh siswa bertahan pada memori jangka panjang siswa, sehingga siswa memperoleh hasil kognitif yang lebih baik. Menurut Setyo (2011: 167) pembelajaran menjadi lebih bermakna jika proses pembelajaran yang dilakukan dapat membangun makna pada struktur kognitif siswa sehingga berkesan lebih lama dalam memori.

Berdasarkan penjelasan di atas dapat disimpulkan bahwa hasil belajar kognitif siswa yang menggunakan LKS IPA terpadu berorientasi model Pembelajaran Berbasis Masalah lebih baik daripada hasil belajar psikomotor siswa yang tidak menggunakan LKS IPA terpadu berorientasi model Pembelajaran Berbasis Masalah. Hal ini berarti LKS IPA terpadu berorientasi model Pembelajaran Berbasis Masalah efektif pada hasil belajar kognitif.

\section{KESIMPULAN DAN SARAN}

Lembar kegiatan siswa IPA Terpadu berorientasi model Pembelajaran Berbasis Masalah dinyatakan sangat efektif berdasarkan hasil belajar kognitif siswa. Lembar kegiatan siswa IPA Terpadu berorientasi model Pembelajaran Berbasis Pembelajaran Berbasis Masalah memungkinkan pembelajaran yang bermakna, sehingga menyebabkan pengetahuan yang diperoleh siswa bertahan pada memori jangka panjang siswa, sehingga siswa memperoleh hasil kognitif yang lebih baik
Selain pemanfaatan LKS IPA Terpadu berorientasi pembelajaran berbasis masalah juga diperlukan media atau sumber belajar lain yang mengembangkan pengetahuan, sikap dan keterampilan siswa. Sarana dan prasarana yang memadai diperlukan untuk dapat menerapkan kegiatan pembelajaran dengan menggunakan LKS IPA Terpadu berorientasi Pembelajaran Berbasis Masalah

\section{DAFTAR PUSTAKA}

Af'idah, A. R., Erman dan M. Budiyanto. 2013. "Penerapan Model Pembelajaran Berdasarkan Masalah Pada Pembelajaran IPA Terpadu Tema Korosi Besi Untuk Siswa Kelas VII SMP Negeri 1 Bungah Gersik". Jurnal Pendidikan Sains e-Pensa Vol. 1 (1) Hal. 66-70.

Ahmadi, I. K. dan S. Amri. 2014. Pengembangan dan Model PembelajaranTematik Integratif. Jakarta: Prestasi Pustakaraya.

Bariroh, S. L., Muchlis, dan A. N. M. Fauziah. 2014. "Pengembangan Lembar Kerja Siswa (LKS) IPA Terpadu Berbasis Pembelajaran Berdasarkan Masalah Tema Polusi Cahaya Kelas VIII MTs Negeri Ngronggot Nganjuk". Jurnal Pendidikan Sains e-Pensa Vol. 02 (01) Hal. 123-128.

Jalilehvand, M. 2012. "The Effect of Text Lenght and Picture on Reading Comprehension of Iranian EFL Students". Journal Asian Social Science Vol. 8 (3) Hal. 329-337.

Minarti, I. P., S. M. E. Susilowati, dan D. R. Indriyanti. 2012. Perangkat Pembelajaran IPA Terpadu Bervisi SETS Berbasis Edutainment Pada Tema Pencernaan. Journal of Innovative Science Education Vol 1 (2) Hal. 105-111.

Rusman. 2010. Model-Model Pembelajaran Mengembangkan Profesionalisme Guru. Jakarta: Rajagrafindo Persada.

Setyo, A. 2011. Pembelajaran Bermakna Berpendekatan SETS Pada Pelajaran Biologi Untuk Menumbuhkan Kepedulian Terhadap Lingkungan. Bioma Vol. 1 (2) Hal. 161-170.

Sudijono, A. 2007. Pengantar Evaluasi Pendidikan. Jakarta: RajaGrafindo Persada. 
Tan, O.S. 2009. Problem-Based Learning And Creativity. Singapore: Cengage Learning Asia Pte Ltd. 